\section{Sustainable Horticulture: An Overview}

\section{Robin G Brumfield'}

A fter World War II, the research, extension, and teaching programs of land-grant universities in the United States fo cused on reducing crop production costs by substituting other inputs for labor in horticultural production. Lower costs of producing the same or better-quality products was the most important goal. The switch from labor to other inputs resulted in tremendous efficiencies in production. In 1940, there were 6.3 million farms in the United States. By 1992, only 2.1 million farms were providing agricultural products to a much larger population (Table 1).

Advances in technologies, mass production systems, and varieties resulted in lower production costs and an abundant, low-cost supply of food in the United States. New horticultural production, marketing, and postharvest technologies have resulted in huge increases in production and year-round availability of fresh produce. Theproducts also have eye appeal and a long shelf life.

This emphasis on lowering crop production costs has resulted in dependence on petrochemicals for controlling insects, diseases, weeds, plant growth, fruit set, and other physiological plant functions. Early varieties of poinsettias, for example, were very tall, and growers used labor to bend the stems over and tie them to make them shorter. Subsequently, labor, thelargest input cost in greenhouseproduction, was replaced by chemical growth regulators. Technology and science also can be used to reduce dependence on chemicals. Breeders can work on breeding varieties of poinsettias that areshort and do not require physical bending of thestems or application of chemical growth regulators. Advances also have been made in postharvest life of poinsettias by breeding new varieties that have a longer shelf life. This shift away from labor-intensiveagriculturehas resulted in tremendous efficiencies in production.

After the World War II era, environmental awareness slowly grew. This awareness accelerated after theenergy crisis of the 1970s (Daberkow and Reichelderfer, 1988) and now is one of the major issues in the world, as evidenced by the United Nations Conference on Environment and Development held in Rio de Janeiro in June 1992.

${ }^{1}$ Rutgers Cooperative Extension, New Brunswick, N.J.

\section{Environmental issues}

Environmental issues in agriculture, and especially horticulture, are many:

- Pests becomeresistant to chemicals because of heavy use. As a result, pesticide formulations must be changed continually, often at great expense. For example, in the 1950s, corn growers began using cyclodienes to control corn rootworms. Within a decade, corn rootworms developed resistance to cyclodienes (Ball and Weekmann, 1962).

- Groundwater in many areas has become contaminated by fertilizers and pesticides. By 1988 , theU.S. Environmental Protection Agency (EPA) had detected 46 pesticides, including some carcinogens, in groundwater (GAO, 1991). The Kansas State Board of Agriculture created a Pesticide Management Area for Atrazine after tests showed high levels of the herbicide in certain drinking-water supplies (Studer, 1992).

- A survey by the U.S. Geological Survey found that $90 \%$ of the samples of surface water from 10 midwestern states contained agricultural chemicals (Hess, 1991). Cleaning up contamination of groundwater or surface water can be costly; however, if contamination is not cleaned up, costs will continue to rise.

- Farmers increasingly are concerned about applicator safety for themselves and their employees.

- Consumers increasingly are concerned with food safety and the chemicals in their food supply and environment.

Since the early 1970 s, the public at large has been increasingly interested in costs to the environment, applicator health, and food safety. Pesticide companies have responded by attempting to replace extremely toxic chemical pesticides and herbicides with less-toxic alternatives (Darling, 1991).

Until recently, economists haveviewed these environmental and other costs as externalities. Recently, however, many analysts have pointed out that these costs are not external to the system; they are a direct output of the system. We in agriculture have referred to some of the outputs as waste products. Now we need to calculate these costs and include them directly into production budgets.

Table 1. Changes in U.S. farms, $1940-90{ }^{2}$

\begin{tabular}{lcc}
\hline & 1940 & 1990 \\
\hline U.S. population & $132,164,569$ & $248,709,873$ \\
Total workers & $51,742,000$ & $117,491,000$ \\
Farm workers & $8,995,000$ & $2,848,000$ \\
Farm workers as \% of workers & 17 & 2 \\
Farm workers as \% of total & 6.8 & 1.1 \\
Number of farms (million) & 6.3 & 2.1 \\
Average farm size (acres) & 168 & 467 \\
\hline
\end{tabular}

Those in agriculture who focussed on consumers' concerns about the safety of chemicals in thefood supply may havethought that theseissues were the result of short-term hysteria, but concern about the global environment appears to bealongterm trend (Harris, 1987).

\section{Sustainable agriculture defined}

Sustainable agriculture is a philosophy that attempts to recognize that these costs are not externalities. It is based on human goals and on understanding thelong-term impacts of our activities on the environment and other species. Using this philosophy guides our application of prior experience and the latest scientific advances to createintegrated, resource-conserving, equitable farming systems. These systems reduce environmental degradation, maintain agricultural produclong term, and maintain stable rural communities and quality of life (Francis and Youngberg, 1990).

In the 1990 farm bill, the U.S. Congress defined sustainableagricultureas "an unintegrated system of plant and animal production practices having a site-specific application that will, over the long term: satisfy human food and fiber needs; enhance environmental quality and the natural resourcebase upon which theagricultural economy depends; makethemost efficient use of nonrenewable resources and on-farm resources and integrate, where appropriate, natural biological cycles and controls; sustain the economic viability of farm operations; and enhance the quality of life for farmers and society as a whole."

Early discussions of low-input sustainable agriculture (LISA) focused on the differences between the conventional agriculture paradigm and ecologically sustainable agriculture (Beus and Dunlap, 1990). Some discussions were highly polarized; however, most researchers and farmers now recognize that today's agriculture can be improved by incorporating techniques designed to make farming more environmentally safe and less economically risky. The farm crisis of the 1980s made people realize that the definition of sustainable agriculture should include an economic component (O'Connell, 1991).

In the 1990 farm bill, the United States Congress renamed the LISA program. In recognitivity, promote economic viability in the short and 
tion of the fact that the goals of sustainableagriculture will be met by a wide range of old and new techniques and strategies, the program is now called sustainableagriculture research and education (SARE). This change in terminology is a good one; it reflects the fact that the changes we are witnessing are not necessarily a shift to lower inputs, rather to different inputs.

\section{Attitudes of advocates of sustainable agriculture}

In general, advocates of sustainable development envision asociety that does not jeopardize the prospects of future generations as it satisfies its own needs (Brown et al., 1990). Advocates of sustainable agriculture, therefore, believe in appropriate scientific and technological progress. Appropriate technology applied to development problems is not harmful to the environment, but fits in the biophysical and socioeconomic parameters of the environment on which it is imposed (Batie, 1988).

Many advocates of sustainable agriculture believe that the biosphere imposes limits on and provides opportunities for economic growth. The environment's ability to assimilate pollution from peoples' activities is the ultimate limit to economic growth (Batie, 1989). Because the extinction of species is an irreversible change that results in less-diverseecosystems, it leads to alower quality of lifefor humans (Ehrlich, 1988). Wild biodiversity can provide plants that are useful to humans (Iltis, 1988).

Most advocates of sustainable agriculture are reluctant to accept environmental risks and believe that actions taken must not harm people or nature. They advocate environmental justice and egalitarian ethics. They believe that all people must be given equal access to natural resources and a quality environment. They seek to limit population growth and to invest in human capital.

The scientific and regulatory communities have identified three major goals of sustainable agriculture: to improve farm-level profitability, to improve the international competitiveness, and to reduce environmental damage by farming practices (Harsch, 1991).

Environmental organizations had a much bigger say in drafting the farm bills passed since 1985 (Table 2). Those bills were confined primarily to program crops, except for the funding for research on alternative farming for all of agriculture in the 1985 farmbill. The 1985 farm bill madeparticipation in programs such as commodity price supports, crop insurance, and certain loans contingent on compliance with environmental objectives. For example, the Highly Erodible Land program gave farmers until 1990 to develop a conservation plan and until 1995 to implement it. Legislation may include horticulture in the future, and, if legislation does not encourage horticulturists to move toward more sustainable systems, the marketplace will.
The Federal Agricultural Improvement and Reform Act of 1996 (FAIR) has been called the greenest farm bill ever. It establishes several new environmental initiative such as the Environmental Quality Incentives Program (EQIP), which provides cost-share and technical assistance to help agricultural producers meet environmental challenges. The Conservation Farm Option and Farms for the Future programs offer producers voluntary, incentive-based conservation partnerships. FAIR also continues the Conservation Reserve and Wetlands Reserveprograms. By changing thecrops subsidy programs, FAIR will give farmers more flexibility to use sustainable agriculturepractices such as crop rotation and the use of fewer synthetic fertilizers and pesticides.

Sustainable agriculture is NOT

- a break with modern agriculture,
- another name for organic farming,

- only for small farms,

- only for livestock,

- a step backwards,

- a panacea for all environmental problems,

- a complete solution to farm profitability problems, or

- a budget-buster for USDA.

However, it is designed to develop a full range of options for all farmers and not to impose limitations on any farmer.

\section{Sustainable agriculture practices}

Farmers use various combinations of the following practices to farm sustainably: crop rotations; pest-control strategies that do not harm nontarget species, farm workers, neighbors of farms, or con-

Table 2. Farm legislation affecting sustainability, 1862-85.

\begin{tabular}{|c|c|c|}
\hline $\begin{array}{l}\text { Farm } \\
\text { Act }\end{array}$ & $\begin{array}{l}\text { Key public } \\
\text { concerns }\end{array}$ & $\begin{array}{l}\text { Provisions affecting } \\
\text { sustainability }\end{array}$ \\
\hline 1862 & Building a nation & Homestead Act subsidized, sodbusting \\
\hline 1935 & $\begin{array}{l}\text { Drought, wind erosion, } \\
\text { farm bankruptcies, } \\
\text { conservation }\end{array}$ & $\begin{array}{l}\text { USDA Soil Conservation Service } \\
\text { (SCS) created }\end{array}$ \\
\hline 1936 & $\begin{array}{l}\text { Conservation and crop } \\
\text { surpluses }\end{array}$ & $\begin{array}{l}\text { Direct payments by SCS to } \\
\text { farmers to subsidize } \\
\text { conservation practices }\end{array}$ \\
\hline 1949 & $\begin{array}{l}\text { Surpluses, low prices, } \\
\text { and erosion }\end{array}$ & $\begin{array}{l}\text { USDA price supports link } \\
\text { production control with } \\
\text { conservation programs }\end{array}$ \\
\hline 1956 & $\begin{array}{l}\text { Surpluses, low prices, } \\
\text { and erosion }\end{array}$ & $\begin{array}{l}\text { Long-term Soil Bank and Great } \\
\text { Plains Conservation programs } \\
\text { launched to idle erodible land } \\
\text { for up to } 10 \text { years }\end{array}$ \\
\hline 1965 & Meeting export demand & $\begin{array}{l}\text { Acreage reduction programs } \\
\text { replaced by fencerow-to- } \\
\text { fencerow planting (early } \\
\text { 1970s) }\end{array}$ \\
\hline 1977 & $\begin{array}{l}\text { Cost effectiveness; } \\
\text { paying farmers not to } \\
\text { produce }\end{array}$ & $\begin{array}{l}\text { Cost-sharing assistance } \\
\text { limited to identified } \\
\text { conservation needs }\end{array}$ \\
\hline 1981 & $\begin{array}{l}\text { Meeting global food } \\
\text { demand }\end{array}$ & $\begin{array}{l}\text { Conservation cost-sharing } \\
\text { rules tightened to separate } \\
\text { conservation from production } \\
\text { control }\end{array}$ \\
\hline 1985 & $\begin{array}{l}\text { Surpluses, conflict } \\
\text { between price support } \\
\text { programs and conservation }\end{array}$ & $\begin{array}{l}\text { Conservation Reserve Program, } \\
\text { Sodbuster, Swampbuster } \\
\text { programs; research on } \\
\text { alternative farming }\end{array}$ \\
\hline 1990 & $\begin{array}{l}\text { Impact of agriculture } \\
\text { on the environment, food } \\
\text { safety }\end{array}$ & $\begin{array}{l}\text { Flexibility in planting, crop } \\
\text { use, crop rotation and } \\
\text { marketing; incentives to } \\
\text { change resource use; greater } \\
\text { research and technical } \\
\text { assistance }\end{array}$ \\
\hline 1996 & $\begin{array}{l}\text { Allowing market forces } \\
\text { to work, removing } \\
\text { government restrictions }\end{array}$ & $\begin{array}{l}\text { Reform of subsidy programs } \\
\text { linked to specific crops, } \\
\text { incentives for environmental } \\
\text { protection }\end{array}$ \\
\hline
\end{tabular}


sumers; mechanical and biological weed control; soil and water conservation practices; animal and green manures; and agricultural chemicals that do not posesignificant threats to humans, animals, or the environment (O'Connell, 1991).

Key questions for researchers and farmers may include the following: What management factors affect sustainability? What crops can be grown using sustainable agriculture practices? How can inputs best be manipulated? Must farmers accept lower profits for doing the right thing? What new technologies and practices will assist farmers in moving toward sustainable farming?

This colloquium was convened to address what is happening in the United States to make horticulture more sustainable. Thefollowing papers are presented by university researchers and others who have been involved in sustainable programs and by national project directors who develop guidelines for sustainable university programs.

These papers provide an overview of SARE, a discussion of waste streams in greenhouse production, a description of a multi-state project that evaluates the feasibility (biologic and economic) of using sustainableagriculturepractices for small fruit, a description of a computer model (PLANETOR) that allows farmers to evaluate alternative resource management strategies, and a discussion of sustainable landscaping.

We in the horticulture community have a difficult task to address environmental issues. The market is now global. Land prices in many states are now too expensive to practice labor-intensive farming. We face many restraints as we work for solutions. We need to find systems that are not only environmentally sustainable, but also economically viable for the producers.

\section{Literature Cited}

Ball, H.J. and G.T. Weekmann. 1962. Insecticide resistance in the adult western corn rootworm in Nebraska. J. Econ. Entomol. 55:439-441.

Batie, S.S. 1989. Sustainable development: challenges to the profession of agricultural economics. Amer. J. Agr. Econ. 71(5):1083-1101.

Beus, C.E. and R.E. Dunlap. 1990. Conventional versus alternative agriculture: the paradigmatic roots of the debate. Rural Sociol. 55(4):590-616.

Brown, L.R., C. Flavin, and S. Postel. 1990. Picturing a sustainable society. In: State of the world: 1990. Norton, New York.

Daberkow, S.G. and K.H. Reichelderfer. 1988 Low-input agriculture: trends, goods, and prospects for inputuse. Amer. J. Agr. Econ. 70(5):11591166.

Darling, D.R. 1991. Research and education in the western region. In: Sustainable agriculture research and education in the field: A proceedings. National Academy Press, Washington, D.C.

Ehrlich, P.R. 1988. The loss of diversity: causes and consequences. In: E.O. Wilson (ed.). Biodiversity. National Academy Press, Washington, D.C.

Francis, C.A. and G. Youngberg. 1990. What is sustainableagriculture? In: C.A. Francis, C. Butler Flora, and L.D. King (eds.). Sustainable agriculture in temperate zones. Wiley, New York.

Harsch, J.H. 1991. Assessing the progress of sustainable agriculture research. In: Sustainable agriculture research and education in the field: $\mathrm{A}$ proceedings. National Academy Press, Washington, DC.

Harris, L. 1987. Inside America. Random House, New York.

Hess, C.E. 1991. The U.S. Department of Agriculture commitment to sustainable agriculture. In: Sustainable agriculture research and education in the field: A proceedings. National Academy Press, Washington, DC.

Iltis, H.H. 1988. Serendipity in the exploration of biodiversity: what good are weedy tomatoes? In: E.O. Wilson (ed.). Biodiversity. National Academy Press, Washington, D.C.

O'Connell, P.F. 1991. Sustainable agriculture. In: U.S. Department of Agriculture. In: Agricultureand the environment: The 1991 yearbook of agriculture. U.S. Government Printing Office, Washington, DC.

Schaller, N. 1991. Background and status of lowinput sustainable agriculture program. In: Sustainable agriculture research and education in the field: A proceedings. National Academy Press, Washington, DC.

Studer, V. 1992. Panel: Strategies for managing ag chemicals. National Citizens' Conf. on Groundwater, Memphis, Tenn.

U.S. Department of Agriculture. 1991. Agriculture and the environment: The 1991 yearbook of agriculture. U.S. Government Printing Office, Washington, D.C.

U.S. Department of Agriculture. 1991. Policy briefing book: The basic principles of sustainable agriculture. U.S. Government Printing Office, Washington, D.C.

U.S. General Accounting Office. 1991. Pesticides: EPA could do more to minimize groundwater contamination. GAO/RCED-91-75. U.S. Government Printing Office, Washington, D.C.

\section{Welcome to Reality: An Overview of a Low-input Sustainable Agriculture (LISA) Project in Small Fruit}

\section{Barbara L. Goulart ${ }^{1}$}

AdDITIONAL INDEX WORDS. extension education, integrated pest management, raspberry trellising, small fruit pest complexes, raspberry, strawberry, cover crops, floating rowcovers

Summ ARY. An in-the-trenches researcher/ coordinator viewpoint of a northeast regional LISA grant funded from 1989-93 is presented. The specifics of the logistics of coordinating a multi-state grant in a fledgling granting program is emphasized, as well as the evolution of the content and focus of the research directions for the grant Evaluation of Alternative Strategies for Small Fruit Production (Univ. of Vermont Agreement 92-08-01). This was a project in which five states in the northeastern United States proposed to cooperate on a multi-disciplinary project exploring the biological and economic feasibility of selected production practices for small fruit. These practices were selected because they showed potential for increasing net profit by reducing purchased inputs or maximizing yield. Information transfer, before, during, and after the studies was emphasized, using such diverse means as grower experimental plots, the participation of growers in integrated pest management programs, the development and publication of economic data relevant to the projects, the development of a LISA small fruit newsletter, as well as more traditional means of information dissemination such as grower meetings, and trade and scientific publications.

'Department of Horticulture, The Pennsylvania State University, University Park, PA 16802. 